\title{
Fraternity Member Reflections About Civic Values
}

\section{Malinda M. Matney, J. Patrick Biddix, Sarah Arsenoff, Teal Keller, Jennifer Dusendang \& Darin Martin}

To cite this article: Malinda M. Matney, J. Patrick Biddix, Sarah Arsenoff, Teal Keller, Jennifer Dusendang \& Darin Martin (2016) Fraternity Member Reflections About Civic Values, Journal of College and Character, 17:4, 223-240, DOI: 10.1080/2194587X.2016.1230760

To link to this article: http://dx.doi.org/10.1080/2194587X.2016.1230760

曲 Published online: 07 Nov 2016.

Submit your article to this journal $2 \pi$

Q View related articles $\longleftarrow$

View Crossmark data $[\pi$ 


\title{
Fraternity Member Reflections About Civic Values
}

\author{
Malinda M. Matney, University of Michigan ${ }^{\text {a }}$ \\ J. Patrick Biddix, The University of Tennessee, Knoxville ${ }^{\mathrm{b}}$ \\ Sarah Arsenoff, University of California Davis ${ }^{\mathrm{c}}$ \\ Teal Keller, University of Houston Clear Lake ${ }^{\mathrm{d}}$ \\ Jennifer Dusendang, University of Michigan ${ }^{\mathrm{e}}$ \\ Darin Martin, University of Michigan ${ }^{\mathrm{f}}$
}

\section{Abstract}

Fraternity members are exposed to developmental opportunities through service, leadership, and involvement, guided by organizational values. The purpose of this study was to learn more about how members interpret their experiences in relation to civic values. Data sources were responses from essays $(n=196)$ written by graduate and undergraduate members of an international fraternity. Results from thematic analysis evidenced a range of applications, from a literal interpretation of rules to a broader sense of agency in the world. Discussion focuses on addressing gaps in what members are learning based on the core tenets of NASPA's Civic Learning and Democratic Engagement (CLDE).

For more than a century, higher education's charge has been to prioritize civic learning and democratic principles as ways to foster citizenship (Dey \& Associates, 2009; Harper, 1905). In a contemporary reemphasis, student affairs practitioners have been called to take a more active role in these activities (National Task Force on Civic Learning and Democratic Engagement, 2012). The authors of $A$ Crucible Moment: College Learning and Democracy's Future recognized the role of student affairs in cultivating civic learning, specifying efforts such as creating shared living-learning environments, guiding and advising students as they learn consensus, and helping students establish socially accountable expectations as ways of promoting social responsibility. Unfortunately, many scholars associate these concepts primarily with classroom-based or service-oriented activities when mapping learning environments (see Finley, 2011),

\footnotetext{
${ }^{a}$ Malinda M. Matney (mmatney@umich.edu) is director of assessment for the Center for Research on Learning and Teaching and assistant professor of higher and postsecondary education at the University of Michigan.

bJ. Patrick Biddix (pbiddix@utk.edu) is associate professor of higher education at the University of Tennessee, Knoxville.

${ }^{\mathrm{c}}$ Sarah Arsenoff is academic coordinator for student housing at the University of California, Davis.

${ }^{\mathrm{d}}$ Teal Keller is coordinator for orientation and new student programs at the University of Houston, Clear Lake.

'Jennifer Dusendang (jdusenda@umich.edu) is a master's student in public health at the University of Michigan.

fDarin Martin (dcmart@umich.edu) is a master's student in higher and postsecondary education at the University of Michigan.
} 
despite research linking campus social involvement and student leadership to the development of civic values (Lott, 2013).

Historically, college fraternities were founded on ideologies related to change and shared decisionmaking (Anson \& Marchesani, 1991) — values linked to civic and democratic principles (Roberts \& Huffman, 2005). In the decade since the Franklin Square Group (2003) published $A$ Call to Values Congruence, several inter/national organizations, including the National Interfraternity Conference (NIC), have reemphasized the importance of incorporating founding values in recruitment activities, the new member education process, and the membership experience. The goal of this study was to examine how fraternity members related their values and actions to some of these concepts. Using document analysis of member essays, we sought to (a) identify how fraternity members related their involvement to civic values and (b) recommend ways to foster these ideals.

For the purposes of this study, fraternity refers to a single-sex, social-oriented group belonging to an inter/national organization. Although there are many conceptions of civic values (e.g., see Finley, 2011), to situate the present study in the contemporary literature, we adopted NASPA's (2014) Civic Learning and Democratic Engagement (CLDE) focus area (NASPA, 2016) as a framework for the discussion of study results. The core tenets of the CLDE include democratic participation, appreciation of diversity, applied learning, and social responsibility.

\section{Review of Literature}

A review of literature about civic values and social responsibility suggests campus involvement can stimulate civic capacity-building among students, particularly through service learning (Butin, 2010; Dugan \& Komives, 2010), interaction with diverse others, (Hurtado \& DeAngelo, 2012), and socially responsible leadership (Dugan, 2008). The studies synthesized in this review relate fraternity involvement to these experiences and consider how fraternity values might mirror civic values. Unfortunately, what we know about the potential link between civic learning and fraternity membership is constrained by a prevalent limitation in the literature on this population. Few researchers disaggregate fraternity and sorority membership when modeling the influence of membership, which can significantly affect outcomes-based studies (Biddix, Matney, Norman, \& Martin, 2014). With two exceptions (Dugan, 2008; Jackson \& Iverson, 2009), research synthesized in the following review shares this limitation.

\section{Fraternity/Sorority Activities as Civic Learning Activities}

Researchers have found fraternity and sorority members have higher levels of community service engagement than non-members (Hayek, Carini, O’Dey, \& Kuh, 2002). Although this difference might be partially attributed to increased opportunities to serve, such as national philanthropy and local community partnerships, students who anticipate joining fraternities also intend to participate in service during college (Cruce \& Moore, 2007). These results hold even after statistically controlling for predispositions to volunteer in college. Using data from the 2005 and 2006 National Survey of Student Engagement (NSSE), Cruce and Moore (2012) reported that students who joined a fraternity or sorority had a $22.4 \%$ greater probability of volunteering during their first year of college than their non-member peers. This evidence led the researchers to suggest that, "fraternities and sororities have some impact on volunteerism over and above what their members bring to such organizations" (p. 411). 
Findings related to interacting with diverse others are somewhat more complex. Using data from the National Study of Student Learning (NSSL), Pascarella, Edison, Nora, \& Edison (1996) found fraternity and sorority members were less open to diversity in the first year of college; in general, students encountered more diverse perspectives when randomly assigned to residence halls. When Asel, Seifert, and Pascarella (2009) considered first- and fourth-year students, they found membership during the first year tended to inhibit interactions and experiences with diverse others but did not report a similar finding for seniors. Drawing on longitudinal data from the Cooperative Institutional Research Program (CIRP), Hurtado, Ruiz, and Whang (2012) found first-year fraternity and sorority members had lower scores on understanding of self and others, civic awareness, and changes in pluralistic orientation.

Using a different measure, recent evidence from the Wabash National Study of Liberal Arts Education (WNS) showed measures of intercultural effectiveness were comparable among members and non-members during the first year (Martin, Hevel, Asel, \& Pascarella, 2011). This finding led the researchers to suggest that although fraternal organizations are often perceived as comprised of likeminded and similar-characteristic members, membership profiles may be broadening to include more members of different races, religious preferences, and sexual orientations. One potentially confounding variable is members' level of involvement. Long and Snowden (2011) found chapter officers experienced greater gains on a diverse interactions measure than members, although the effect was small $(d=0.10)$.

Findings linking fraternity involvement and measures of social responsibility seem highly dependent on how outcomes are evaluated. Results from two studies using nationally representative data illustrate this criticism. Using the Socially Responsible Leadership Scale (SRLS) as part of a multiinstitution, national research project examining influences on college student leadership development, Dugan (2008) found fraternity members scored highest on commitment and lowest on change, consistent with national norms for the dataset. Additionally, Dugan found member scores for controversy with civility, citizenship, and navigating change (values linked to civic learning) lowest among all measures. Conversely, using a multi-faceted outcome measure, Bureau, Ryan, Ahren, Shoup, and Torres (2011) reported different results for fraternity and sorority members. Drawing on data from the senior-year administrations of the NSSE, researchers found members surpassed non-members on personal and social development, a composite score representing outcomes characterizing interpersonal effectiveness, ethical grounding, social responsibility, and civic-mindedness.

Researchers also have considered links between leadership participation and civic learning by examining student views and actions related to social responsibility and change. Soria, Fink, Lepkowski, and Snyder (2013) defined engagement in social change as the extent to which students reflected on personal and social responsibility, suggested solutions for social problems, discussed solutions to community problems, and acted upon community and social issues outside the classroom. Using data from the multi-institutional Student Experience in the Research University (SERU) survey, the researchers found leadership in advocacy groups, fraternities and sororities, political organizations, religious organizations, and community service organizations was associated with higher engagement in social change. Unfortunately, the researchers did not report whether they controlled for multiple group membership, which previous researchers (e.g., Bartholow, Sher, \& Krull, 2003) have shown can influence similar outcomes.

\section{Fraternity/Sorority Values as Civic Values}

A critical review of two decades of research about fraternities (Biddix et al., 2014) revealed few published studies focused on how members adopt or exhibit civic values. This finding was somewhat surprising, 
given the core values of fraternities - self-governance, personal responsibility, and responsibility for others (Earley, 1998; Matthews et al., 2009) - mirror civic ideals (Colby, Ehrlich, Beaumont, \& Stephens, 2003; Dey \& Associates, 2009). A review of the two related studies considering links among fraternity values and actions and civic values follows.

Matthews et al. (2009), using a document analysis of creeds, mission, and/or purpose statements of 38 inter/national fraternities and sororities, identified five common values: civic engagement, commitment to organization, fostering community, integrity, and pursuit of knowledge. The researchers defined civic engagement as "engagement in and commitment to society," noting that "contributions to community, organization, God, mankind, country, and alma mater all qualify as ways for an individual to be a good citizen" (p. 34). Afterward, the researchers compared fraternity and sorority creeds and mission statements to member actions they qualitatively observed to assess congruence with stated versus enacted values. While links might be drawn between several espoused/observed pairs (commitment to organization; fostering community/connectedness; pursuit of knowledge/academic excellence), aspects of the espoused civic engagement value were not apparent to the observers. They perceived behaviors associated with "engagement in and commitment to society" as more narrowly related to the individual organization and alma mater.

Jackson and Iverson (2009), using focus groups and interviews with students at a private research university in the Midwest, considered how members related their involvement to awareness about social concerns, changes in values and beliefs, and desire to take action in their community. The researchers identified three themes from their analysis: awareness, values, and action. Two of the fraternity members connected their growth in awareness to service projects that allowed them to interact with others in settings different from their own. Another member discussed how participating in the interfraternity council, a group representing the majority of fraternities on campus, gave him a more holistic view of the larger fraternal community. Participants related personal values, the second theme, to a heightened sense of social responsibility, feelings of connectedness to their community, and commitment and accountability in decision making. One member discussed the role of chapter ritual in teaching him community values and self-responsibility, noting that as he grew to understand the words and actions of the ritual, he began to see his actions as a reflection of the fraternity. Extending this to the larger fraternal community, he recognized that adopting fraternal values improved chapter and community norms, leading to better citizens. Another member mentioned that considering personal values as part of decision making helped him realize the importance of maintaining community standards and accountability. Lastly, participants defined action as performance of their internalized beliefs regarding commitment, responsibility, and value internalization. Collectively, the members defined taking action as, "fulfilling one's responsibility, making a difference, and helping others" (p. 10) as essential requirements in their conception of citizenship.

\section{Summary}

Conceptually, fraternity members are exposed to opportunities for civic learning through service, leadership, and in some cases through reflection on their founding values (i.e., ritual). Results from empirical research have been mixed when associating these ideals to positive beliefs or interpersonal growth. The purpose of this study was to learn more about how members make meaning of their membership experiences in relation to these broader ideals. 


\section{Method}

A central research question guided research design and data analysis: How do fraternity members relate their membership experiences to civic values? Data informing this study were based on a content analysis of essays written by undergraduate and graduate members of an international fraternity. We obtained organizational and IRB approval and de-identified all data prior to analysis to protect confidentiality, as modeled in similar studies using existing qualitative records (McMillan \& Morrison, 2006; Wuthrich, 2009).

Secondary data analysis, in which the researcher reviews existing data, as opposed to generating new records, has advantages and challenges over more direct methods such as survey and interviewing. McMillan and Morrison (2006) noted, "Documents are an important data source for qualitative researchers because the information they provide may differ from, or not be available in, spoken form, and because the enduring nature of the texts offers opportunities for historical insight" (pp. 75-76). Since presence of the researcher is not altering what is studied, document review can help reduce potential bias and improve validation strategies by removing the effect of the researcher's presence (Bogdan \& Biklen, 1998). In addition to benefits related to efficiency (e.g., low cost, reduced time for data collection), documents are stable records created for a specific purpose. Documents can also be a limitation, particularly when records are used outside of their intended creation, as in the case of this study. Additional challenges include that records generally lack context without insider knowledge of their creation, can include incomplete or altered data, and are non-interactive (Love, 2003). We discuss these challenges further as limitations to the study.

\section{Data Sources and Analysis}

Data sources were the essay responses of 196 student members. Members initially submitted the essays as a requirement of a fraternity scholarship program in 2011. Each applicant was provided with an excerpt from Seth Brooks's "Freedom's Twins" (Appendix A), an essay about civility with themes of responsibility, discipline, common sense, and gentleness. Applicants were asked to relate the essay themes based on the following prompt: How can you apply Seth Brooks's essay on "Freedom" to life and the choices you make? There was no recommended length for the essays, although the median length was between 500-600 words, totaling 280 pages of text. Participant characteristics included students from 77 institutions, with the majority seniors (81), followed by juniors (65), sophomores (37), freshmen (6), and graduate students (7).

Within this specific fraternity's context, essays from Seth Brooks are often used as a starting point for discussion about aspects of fraternity life. For example, at the regional training workshops for chapter officers (workshops to which every campus is obliged to send at least eight student members), a Seth Brooks essay starts the conversation among all students about their responsibility as leaders to leave a better organization than the one they discovered. A textbook of Seth Brooks' essays and writings (Brooks, 1986) is incorporated as part of the established library of this fraternity. While there is no explicit prompt to invite students to relate the Brooks essay to fraternal life, every description of his work makes clear the intent within the fraternity that his essays be seen in that context, almost to the limitation of students' ability to apply Brooks' writings to their greater world.

Data analysis involved a priori coding (Weber, 1990) based on the established themes (responsibility, discipline, common sense, and gentleness) from the essay. Instead of defining each theme, Brooks related 
each to the overall theme of freedom. We initially examined the passages for positive and negative examples of each theme as depicted by the author, such as "this is an example of me living with this theme," or "this is how I was out of line with this theme." We performed these steps individually, and then we met to review coding. Despite using different words to describe findings, there was general agreement when relating examples to themes. In instances where we had differing interpretations, we discussed the findings as part of the final analysis. Once we agreed on common descriptions, we re-reviewed essays to identify passages that signified agreement or disagreement. To establish credibility, each coder was provided with the same 20 essays to review prior to analysis so that inter-coder reliability could be established. In addition, we asked an expert reviewer to randomly select and review 10 essays from the full dataset to ensure final themes were accurately reflected.

\section{Limitations}

Members who submitted the essays were applying for an award, so there is a risk that they wrote simply what they thought the judges wanted to see. We believe this limitation was lessened by the question prompt; applicants were asked to reflect broadly on personal values related to the essay. We also acknowledge that the study results may not be generalizable beyond the fraternity. However, as the intent of the study was to provide an initial consideration of how fraternity involvement might be related to civic related-values, a goal was to direct and stimulate additional research. Nonetheless, we believe there is some transferability to similar contexts; while there are individual differences between fraternal organizations, many of the missions and core values are similar (Earley, 1998; Matthews et al., 2009).

The award applicants may not be representative of the majority of members. For example, several had held leadership positions in the fraternity and/or were involved in additional campus groups. As a result, there is a risk that the data might represent an ideal perspective of members who are more engaged or invested in their organizations. To minimize this limitation, we introduced two additional checks. First, to account for length of membership, we separated data and compared themes from new members ( 1 year or less) from the rest of the sample. Second, to account for leadership experience, we separated and compared records for members who had held offices or attended fraternity-sponsored leadership training. Aside from a few outliers, leadership and length of involvement in the fraternity did not seem to make a significant impact in their reflections. As expected, members who had attended leadership experiences were more likely to compare their experiences to organization values. However, we view this as evidence for the value of leadership programming in offering opportunities for members to connect their involvement to personal development.

Finally, Marshall and Rossman (1995) cautioned, "the researcher's challenge is to demonstrate that this personal interest will not bias the study" (p. 17). One of the researchers is an alumnus of the fraternity studied. Another is a volunteer for fraternity national leadership programming. Neither was involved in coding data. To account for these potential influences, trained student researchers, who were not affiliated with the organization, completed data analysis. The students were not told the name of the inter/national fraternity or that either lead researcher had any tie to the organization.

\section{Results}

In his essay, Brooks referred to responsibility, discipline, common sense, and gentleness as each a twin of freedom, recognizing that each pair provides counter balance. For example, he wrote that, "a free nation can 
survive only if people accept responsibility to maintain laws, whether they like them or not, until such laws are changed by legal process coming through a free democratic electorate" (p. 3). In this way, Brooks did not define each theme in his essay, but introduced each, provided examples, and related each as a sine qua non of freedom; freedom has relationships with many countering concepts. Two interesting observations about the process bear mentioning. First, as we noted in the limitations, age of members, year in school, or officer status did not seem to matter when differentiating the responses, except for men who had attended leadership training. Second, often when members applied the themes to situations they had encountered, they exhibited a higher-ordered conception of one value but not another. For example, one might discuss responsibility as related to accountability to others but then frame discipline as fairness.

In their responses, members related Brooks's themes broadly to their prior college experiences, to hypothetical situations, and to circumstances they encountered in the fraternity. As we sorted essays based on our predetermined prompts ("this is an example of me living with this theme" or "this is how I was out of line with this theme"), we observed applications across a broad range of perspectives. At times, members applied literal interpretation of rules when reflecting on applicable situations. At times, their reflections suggested a broader sense of agency and awareness of civic values. In many instances, the members echoed Brooks's examples with their own interpretations of citizenship development or organizational structure. These were broader applications that suggested members had reflected on these ideals in their academic, fraternal, or other involvements and hinted how those ideals might inform their behavior or approach to different situations. On other occasions, members responded in a proscribed way, revealing a protective and self-interested worldview. Following are examples of their interpretations.

\section{Responsibility}

The responsibility theme gained the greatest response from members, but members seemed to struggle the most with applying this concept. The essays included subthemes of members describing responsible conduct in the fraternity, their experiences as officers, and the need to preserve fraternity values when describing their interpretation of responsibility.

Describing responsible conduct in the fraternity was particularly illustrative in the range of member responses. In advanced application, members described how what they had learned might apply in future opportunities. As one member wrote

It is my duty to take responsibility in my community, act with discipline and common sense in my assumed roles, and greet my fellow man with gentleness. While I have not been part of a struggle for expanded rights, I have felt a responsibility for action and assistance in my community. This sense of responsibility has translated to participation in and organization of community service events.

What is interesting about this essay is the member's recognition that he had not struggled for his own rights, but he felt a responsibility to act. Later, he applied that greater reflection to what he understood tangibly, organizing and participating in community service. Another member framed responsibility as action in this way.

By comparison, another member described a more personal application of this concept in a "do unto others" framing:

The key to converting responsibility from paper to reality is to have pride in one's self and his or her actions. Not in a pompous, egotistical sense, but being able to stand by your actions and values no matter 
what "everyone else is doing." This also goes along with going out into the world with proper confidence and leadership in whatever path one may take. The right move to make, may not be the popular one, but it is the strength and responsibility within that can determine the outcome.

In this example, the member described ordering his own conduct by a personal moral code. It does not speak to relationships with others but rather focuses on internal control. Yet, it still relies on having created an internal behavioral code.

Some responses pursued a different direction, missing the idea of responsibility as a covenant with the larger world. Not only did these responses focus on smaller individual concerns, but they also turned in the direction of preventing others from assuming responsibility for their actions.

As President, I am ultimately responsible for everything that happens in my chapter. I am the functional and relational leader for my group of men. The essence of being a man is taking responsibility. That includes taking responsibility for things that are my fault and things that aren't. As our colony tries to build men on the core values of [the fraternity], I must take responsibility for everything that happens amongst my men.

On the surface, this passage indicates that this officer understood his responsibility for conduct of those around him. Two key differences emerge from the previous concepts. One is that the officer assumed penalty without assuming accountability; his statement that he took responsibility "for things that are my fault and things that aren't" indicated that he was focused on actions and not the causes or principles involved. The officer also wrote that he assumed responsibility for everything rather than confronting those responsible, but nowhere in the passage spoke to the responsibility to confront fellow members about actions. This response suggested that, at times, it was easier to take a penalty than to confront one's peers about negative incidents.

Describing the need to preserve fraternity values showed how members felt their actions reflected on the principles taught by the international fraternity. At their high point, members reflected on how lessons they learned translate to the broader world. Sometimes the relationships revealed moments of discovery.

I did everything except what I should have been doing, which was studying or trying to get involved. However, all that changed when two older members in the house approached me and told me about the potential they saw in me. They suddenly became role models to me and I wanted to do everything like them. I started off studying more and being more involved just to impress them, but since then I realize what they really did for me. While they're no longer in the house, I still have this drive to do what's "responsible." I care about grades, I care about getting involved, and I care about the reputation of this house. I have developed a set of values that I stick to that have helped me to become more responsible the older I get.

This member described multiple transitions: from underperformer to achiever and from mentee to mentor. He also described gaining an internal locus of control after being inspired by external motivators. This response was in contrast to members focusing on external locus of control and on removing themselves from engagement:

It is because of [the fraternity's] values that I strive to achieve my very best every day rather than settle for something less. In short, [the fraternity] has taken my moral code and my values and not only surrounded me with others who believe in the same ideals that I do, but also has set a standard for me by which to live.

This example seemed to begin the same way as the previous one. However, this member expressed a position of retreat, moving from internal locus of control to a more cloistered existence in which others set the standard. 


\section{Discipline}

Members related discipline to their personal and fraternity experiences, but more broadly. The essays included examples of members maintaining self-discipline, upholding fraternity values, and following through on chapter values as broad subthemes in describing their discipline in all its forms.

The self-discipline subtheme revealed personal applications of concepts. Given their ages, it is understandable that some members wrote about more personal struggles, such as having the discipline to get out of bed in the morning.

It takes self-discipline to adhere to principles and morals you set for yourself. It is much easier to stay in bed and waste the day away than it is to wake up every morning, go to class and encounter each day's obstacles the best way I can. We all have days where we want to stay home and don't feel like contributing anything to anyone. But, as Brooks said, "The disciplined person understands the bounds and limits in which he can move for his own good and for the good of others."

The transition from getting out of bed to contributing to society seems both simplistic and empowering, as members translated how small actions build toward larger impact. It stands as a positive alternative to members who wrote about discipline as an on-going struggle of morality.

I have been working to maintain the balance myself and share it with others. Knowing that the adulteration of any of these qualities can spiral into an immoral mess, I have lived my life always asking myself, "Will I regret this later?"

The "white knuckling" approach of preventing regret seems unsustainable. Clearly this member saw discipline as deprivation, rather than as commitment to goals and values. This approach did not acknowledge the role of relationships in life choices.

The upholding fraternity values subtheme takes this tension and applies it more directly to day-today chapter life. The challenge of small steps becoming larger habits is clear in this example.

Unfortunately, when brothers fail to self-govern themselves, I have been forced, as chair of the [Discipline] Committee, to intervene and ensure that nobody's freedom is being limited. This is sometimes difficult to do, as these brothers are some of my best friends and the last thing I would want to see is them punished. But sometimes the conditions warrant such actions in order to get this brother back in good standing with the chapter. Sadly, in one instance we were unable to get a brother back in good standing with the chapter under my leadership of the [Discipline] Committee and we were forced to remove him through a trial-bychapter.

Through this example, the member described his work to help others learn discipline or take accountability for it. The focus on having hard conversations and understanding this approach as a key component of friendship was a mature struggle.

The "following through on chapter values" subtheme shows similar principles, but focuses on how members enacted their own fraternal involvement. At times, members found moments in which they could see chapter governance as giving a glimpse into other types of governance.

When policies create clear lines of accountability, individuals may be trusted to a large extent to conduct themselves more responsibly. In order for individuals to grow as people, individuals must be left to weigh the consequences of their own actions. And further, once the aims of citizens are carried through in whatever manner the actors see fit, the individuals must be left to indulge in the spoil of his rewards and growth, or to feel the brunt of negative consequences from his own actions. This should be the aim of 
policy makers and chapter executives, to create clear lines of accountability which will foster an incentive structure which promotes responsibility and trust amongst brothers.

This member reflected on how accountability works. While still struggling to make sense of what creates incentives in the larger society, this member could see relationships in the proximate environment of the chapter and the larger society.

\section{Common Sense}

Members also wrote about common sense much less prominently, albeit in more direct terms and applied less directly to fraternity involvement. The essays included examples of members describing setting realistic goals and making wise choices as broad subthemes in describing their common sense application across aspects of their lives.

The setting realistic goals subtheme spoke of an avoidance of extremes as well as the realization that multiple issues often are in collision on the way to a goal. A clear example is a member describing his work as chapter president.

It took a kick in the rear from my common sense to realize that I had to address one issue at a time and to see that I would do more harm than good if I tried to push the chapter too far. Now I daily rely on common sense to decide which issues as President are worth tackling, and this common sense has given me freedom from overwhelming all parties by trying to do too much.

This member spoke not only to common sense as a skill, but potentially as an excuse not to aspire to higher standards. He was beginning to navigate the balance of when to take on multiple issues, and when to focus on one or two key challenges. At the same time, members often saw this response as a personal mandate to scale down the challenges they give to themselves.

The making wise choices subtheme displayed how common sense invites members to build lives of reflection.

Likewise, common sense dictates that, despite what your mind tells you, you are not infallible. Being a college member with newfound freedoms does not guarantee you the right to do whatever you like. To me, one of the signs of maturity is knowing when to stop, when to step back, and when to change the path you are on. To some extent, I had these values prior to pledging [the fraternity]. But the fraternity and the brotherhood I have found there have given me the chance to develop these values and provided me with constant opportunities for self-examination.

This particular reflection described both life transition and self-correction. Members saw the making wise choices subtheme as helping them to live in a way that would never receive negative feedback, an approach that seemed to be a retreat from the courage Brooks invited earlier in his essay.

A person must have common sense to and know the limits of not just oneself, but the limits of others as well. By having common sense, then one will not ask any impossible demands of others if they themselves know that it cannot be done. One with common sense can make the right choices in life that fits everyone's needs. By making the right choices in life, then one will have no fear of being frowned upon or criticized.

Throughout the common sense theme, members struggled with how to create progressive steps toward a goal while not giving up their ambitions and values. Throughout these member observations, their concerns for acceptance were evident. 


\section{Gentleness}

Members seemed to struggle most with relating gentleness to their life and fraternity experiences. The essays included examples of members describing gentleness in leadership roles and showing patience, kindness, or respect as broad subthemes in describing their gentleness and its relationship to other traits. Its description as personal attention is particularly relevant; that the desire for personal attention is often a reason members choose to join any organization.

Our interaction requires a mutual respect for one another, and I apply this within my own fraternity. We have 120 young men with distinct opinions, yet the way we engage is important in maintaining that each individual has a voice and choice. I cannot force my will upon my brothers, otherwise I fall into the same category as the tyrannical rulers in many parts of the world.

Although a world leader cannot build a personal relationship with each citizen, this member understood he had an opportunity to learn from others and build relationships. His respect for other opinions is one expression of gentleness. This theme of individual relationship building has other expressions.

The showing patience, kindness, or respect subtheme described gentleness as fragile and often in comparison to military might.

Serving is done with gentleness, patience, and kindness. As men, violence is a common determinant of authority. Who is stronger than whom? Who can beat whom? Violence is a competition of pride saturated in ignorance.

Turning away from violence was a striking thread. The nuance of building relationships, which members described in the leadership component of gentleness, was complemented with the realization that violence is not a great alternative.

As members wrote about gentleness, they summarized multiple concepts from the essays. At their high point, some wrote from an optimistic lens.

Gentleness, similarly, requires kindness and understanding. So, in my daily life, I do my best to exercise both qualities together. Personally, I believe it is not enough to simply be intelligent or work toward selfimprovement. Responsible actions and disciplined study are irrelevant if a man acts without understanding. So, as I interact with others every day, I remain deliberately conscious of the importance of kindness toward others, with humble gratitude for the opportunities that my circumstances have provided me.

\section{Discussion}

The student affairs field's conceptions of civic values center on civility, envisaged as living responsibly with one another, learning consensus values, adding a moral compass to behavior, and guiding socially responsibility expectations and consequences (National Task Force on Civic Learning and Democratic Engagement, 2012). We acknowledge that the themes of the Seth Brooks essay do align exactly with these notions. Brooks, as a Universalist minister, wrote within the specific context of his ministry, which predated much of the current canon of the student affairs field. Universalism espouses that key values are universal human qualities, an approach that Brooks took in his essay. Pairing a quality of independence with a quality of responsibility was a clear description of Brooks's own context of universal human qualities. Brooks called on fraternity members to individually internalize and reflect on their own 
development, whereas the recent emphasis on student affairs is in creating and sustaining conditions that foster and support civic engagement (Brooks, 1986).

Another key difference is the student affairs field's emphasis on diversity and appreciation of difference as civic values leading to inclusive and participatory environments where every voice is appreciated and valued. Brooks was writing at a time when diversity considerations were not linked specifically to democratic values; in fact, the ecumenical pan-Western belief approach of Universalism was considered radically inclusive in its day. Brooks' conceptions of civic responsibility are perhaps more closely aligned with William Rainey Harper's (1905) advocacy of a broadly educated and engaged citizenry built on individuals who had internalized these values.

The first goal of this study was to identify ways members related their involvement experiences to civic values. For the purposes of this discussion, we applied NASPA's (2014) CLDE focus area (NASPA, 2016) to discuss findings as related to the core tenets of democratic participation, appreciation of diversity, applied learning, and social responsibility. While a more direct approach of evaluating these ideals among members would have been preferable, viewing results through this lens allowed us to situate findings in the current discussions surrounding civic learning. This approach helped us meet the second goal of the study, to recommend ways civic learning could be fostered by aligning membership actions and experiences with these larger ideals.

Members exhibited the CLDE core tenets to varying degrees, though less directly for respect and not at all for appreciation of diversity. This response was not unexpected because the essay did not have a specific prompt related to diversity. Primarily, member responses highlighted ways they understood or applied their personal and organizational values and how they reacted to and internalized challenges by either retreating from or demonstrating commitment to civic learning and social responsibilities. As expected, there was less consistency among individual responses. However, we documented general themes along a continuum. These ranged from literal interpretation of rules to a clearer sense of their place in the world. Some members were concerned about how their reputations looked (e.g., through grades or what the world believes of them) while others were thinking about where their unseen effects were as either mentors or change agents in the world. A central theme that surfaced from their interpretations of all Brooks's themes was accountability. This finding aligned with more recent literature suggesting how members interpret their organizational values (e.g., McCreary \& Schutts, 2015). A second related theme was responsibility - less so as a larger social concept or even related to their service involvements but more directly applied to reflections on their leadership experiences.

\section{Accountability as "Values"}

Members discussed discipline as having two connotations. For some, discipline equated to having selfdiscipline with regard to choices in life. Others interpreted discipline as accountability to a higher set of community-held values, as espoused by the fraternity. Some wrote about the importance of following through on the expectations of their fraternity. Historically, fraternities were founded on a set of core values related to personal and civic responsibility (Anson \& Marchesani, 1991; Earley, 1998; Matthews et al., 2009; Roberts \& Huffman, 2005), values that fraternity leaders have emphasized (e.g., Franklin Square Group, 2003). Unfortunately, members seldom reach (or at least demonstrate that they are reaching) for these values on their own (Bureau, Schendel, Veldkamp, 2006; Summer; Shalka \& Jones, 2010). This disconnect was evident in the member essays. Members discussed civic-related concepts; however, they rarely extended these beyond the individual organization, consistent with Matthews et al.'s

doi:10.1080/2194587X.2016.1230760

http://journals.naspa.org/jcc

(c) NASPA 2016

JCC 
(2009) work. This suggests that while their organizational values expose them to a framework for some civic-related ideals (e.g., heightened sense of social responsibility, feelings of connectedness to their community, and commitment and accountability in decision-making [Jackson \& Iverson, 2009]), they need an extra push to help them see connections beyond the organization. However, this may be a function of distinguishing values from accountability.

Many interpreted values as standards and discussed fraternity values in terms of accountability to those standards. Recent research (McCreary \& Schutts, 2015) about fraternity conceptions of brotherhood further evidences this trend. McCreary (2014, February) is among fraternity leaders who have called for a shift in conversations from values to brotherhood, emphasizing accountability to each other and to a broader fraternal community. According to McCreary (2014, February), "once they embrace accountability as an essential part of the fraternal experience, the movement to chapters that are congruent with espoused values is inevitable" (p. 3). This emphasis aligns more with both civic learning and social responsibility, and suggests how professionals might express to members the need to link their conception of enacted organizational values to these broader societal ideals. Bryant, Gaston Gayles, and Davis (2012), in theorizing the relationship between civic values and civic behavior, recognized the potential for a direct relationship.

\section{Leadership as Responsibility}

When discussing responsibility, members related stories or anecdotes centered on personal conduct and their experiences, either serving as chapter leaders or watching the behaviors and decisions of chapter leaders. When members told stories about poor decisions they had made or witnessed, they often linked the lessons they learned to the importance of responsible conduct in the fraternity. These expressions varied from the more general rationale of not wanting to make the fraternity "look bad" (more of an accountability conception) to expressions of man's place in society (more closely aligned with social responsibility).

Most of the differences in members' interpretations of the essay emerged when they discussed responsibility in terms of being a chapter officer. Leadership in campus organizations, including fraternities (e.g., Dugan, 2008) has been linked to a variety of higher-ordered outcomes related to socially responsible leadership. Yet, Dugan's (2008) work also revealed that leaders could improve on areas including controversy with civility, citizenship, and change. One way to do this, according to Dugan, is to connect the service orientation of fraternities more directly to leadership by "pressing students to personalize their individual commitments to broader society" (p. 21). A more typical disconnected approach, where service and leadership are treated as separate dimensions of membership, "fails to capitalize on the mutually beneficial and influential learning that can occur from an integrated pedagogy" (p. 21). This lack of connection suggests a missing link between involvement actions and how members make meaning of them.

\section{Linking Actions to Learning}

The second goal of this study was to recommend ways members could foster these ideals. Cruce and Moore (2007) suggested that institutions could take lessons from fraternal organizations with regard to structures they have in place to encourage participation and provide avenues for involvement. The researchers noted, "Students who participate in these activities receive consistent messages about the value and the importance of service" (p. 669). The question is the following: Are fraternity leaders and advocates making the connection between emphasizing participation and understanding what participating means? 
Remarkably absent throughout most of the essays was mention of mentors on campus. Less directly, members discussed others in the chapter they "looked up to" or who "looked up to them" as they took on leadership roles. Occasionally, members referred to other students, and at times to general fraternity figures, but never to faculty and staff on campus. This reaction seemed curious, and is a strange separation of learning environments. This question leads to a broader discussion about the roles of alumni advisors, campus professionals, fraternity leadership (beyond campus), and other advocates for the benefits of fraternity involvement. A decade-long emphasis on values (Franklin Square-Group, 2003) has produced little more than reasoned criticisms of the approach (e.g., McCreary, 2014, February). While some programs (e.g., Fraternal Futures) have shown promise (Roberts \& Johnson, 2006), what seems missing is helping members make connections among their values, actions, and learning. The encouraging part is that the framework and activities offer a rich environment for emphasizing and connecting experience to developmental outcomes; a missing link is mentors to foster these conversations. The authors of A Crucible Moment: College Learning and Democracy's Future recognized the role of student affairs professionals in cultivating civic learning and social responsibility (National Task Force on Civic Learning and Democratic Engagement, 2012).

\section{Appreciating Diversity}

An interesting challenge for fraternities in our current higher educational context is the connection of their mission statements to both their values and to the key issues on campus today, such as diversity. There is not a uniform approach from the variety of national and international fraternities. Some fraternities have origins in exclusion from campus life, and they brought together men who otherwise were not included in the campus climate (Anson \& Marchesani, 1991). A key challenge is that as campuses have included more varied student populations, fraternities have not diversified as quickly as the general campus population. Why they have not diversified, in population or thought, as quickly has many possible reasons. Many students will state that fraternities are valuable because these mini-communities make a larger campus feel smaller. However, for some students, there may be a fine line between simply a smaller group and a group that looks like themselves in a campus that is diverse. Another reason we may not see diversity rising to students' minds is that while mission statements (even the most newly created ones) focus on branding or modern language description of older fraternity values, diversity where it exists is often a learning initiative, and not a central tenet of current fraternity values. Without diversity being an explicit value, students will not see it rise to a high level of importance among fraternity leaders.

While diversity was a not a focal point for this article, respect for others emerged indirectly in the responses related to responsibility and gentleness. In many cases, members discussed both responsibility and respecting others beyond the fraternity as a life value they practiced in their involvement and actions before and beyond the fraternity. Existing structures within the fraternity offer opportunities to help members grow in their exposure to and appreciation for diversity-broadly defined as exploration of privilege, perspective-taking, and societal responsibility (Pettitt, 2008, spring). Yet, Jackson and Iverson (2009) found that members only grew in awareness of others when they participated in service involving interactions with others in settings different from their own. Further, while Matthews et al. (2009) suggested that fraternity programming offers opportunities to connect these concepts, a lack of direct guidance would make this difficult. Appreciation for diversity, particularly given recent news stories centering on fraternityrelated and racially charged incidents, offer a starting point for having deep discussions with members about their historical values related to broader societal concepts of helping others. 


\section{Final Considerations}

In a discussion of fraternity values, Roberts and Huffman (2005) noted, "These same democratic principles operate in other student organizations in which change can be stimulated by tapping into students' interests, addressing local issues in small groups, allowing students to co-create their future, and enriching their understanding of relevant issues" (p. 22). As scholars work to identify and understand how civic values might be taught, it is important to identify, operationalize, and evaluate potential capacity builders among college experiences beyond curricular and service-focused opportunities (Carnegie Foundation, 2006). Understanding how student involvement can contribute to civic learning is essential for educators and policy-makers charged with creating, fostering, and sustaining a campus environment "where education for democracy and civic responsibility is pervasive, not partial; central, not peripheral" (National Task Force on Civic Learning and Democratic Engagement, 2012, p. 2). Further, learning more about identifying, mapping, and supporting forms of student involvement related to civic values can provide evidenced-based outcomes for student affairs work.

The purpose of this study was to understand more about how fraternity members make meaning of their membership experiences in relation civic values. Although based on indirect evidence, this analysis revealed gaps in what they are learning as well as in their ability to relate their experiences. More intentional qualitative work, asking members specific questions about their involvement, would provide a more precise picture. Critical to this type of study would be meaningful questions about who influences their decisions and what mentors or advisors exist for members on campus. Extending this initial work to a larger quantitative study, in comparison or conjunction with McCreary and Schutts's (2015) conceptions of brotherhood, has the potential to provide a basis for educational opportunities (or simply informal conversations) with members to solidify links among individual and organizational values, actions, and outcomes. Bryant et al. (2012) recommended these types of efforts, noting that, "the significance of considering values and behaviors together lies in the reality that an engaged citizenship requires a culmination of valuing the democratic community and desiring to make a difference, as well as actively living out those values in day-to-day life" (pp. 90-91). 


\section{Appendix}

\section{Freedom's Twins by Seth R. Brooks ${ }^{1}$}

Freedom is the cry and demand which rings throughout the world. Everybody wants freedom. It is a passionate desire for men to be free from all kinds of real and imaginary bonds. Some men know it is not just freedom from which humanity needs, but freedom for. We ought to be free for service to mankind, our Nation, our home, our church, and those things which build society a character.

If freedom is coupled with being free from and being free for, it cannot exist long without freedom with. Freedom was born a twin. Just as Liberty was born a twin with eternal vigilance, freedom was born a twin and history knows freedom cannot long exist without its twin.

Freedom was born a twin with responsibility. A free nation can survive only if people accept responsibility to maintain laws, whether they like them or not, until such laws are changed by legal process coming through a free democratic electorate. There is a responsibility to maintain order and not create disorder, and there is a responsibility to preserve civil peace because all people live within a civil structure. Education as it prompts freedom can create anarchy unless those it educates show responsibility in the realms of both ideas and actions.

Freedom was born a twin with discipline. The self-disciplined person is the free person. The disciplined person understands the bounds and limits in which he can move for his own good and for the good of all others. Freedom is the first casualty of undisciplined persons and society. Shouters, rioters, libertines, and unthinking passionate fools without discipline wreck and ruin.

Freedom was born a twin with common sense. Common sense dictates that persons do not go too far. It is restraint in making impossible demands and always being aggrieved, injured, and the object of unfair treatment. The trouble with all our dreams of Utopia is that throughout history there have never been enough people who would voluntarily pay the rent to live in Utopia. Common sense is awareness of the blessings we have received through freedom, and the desire, through reasonable means, to extend blessings to all others. Common sense tells one that freedom must be deserved, earned, and maintained through good, hard, honest effort.

Freedom was born a twin with gentleness. The revolutionary forces of mankind have not understood this. They overlook the fact that violence breeds violence, violence destroys. Violence is self-defeating. Freedom is not established through punitive methods. Freedom is not rushed roughshod into being. It is extended, spread and established through leaders and ordinary persons who have the patience and kindness to show gentleness.

${ }^{1}$ This excerpt from the full essay was provided to all applicants. It is reprinted here with permission. 


\section{References}

Anson, J. L., \& Marchesani, R. F. (Eds.). (1991). Baird's manual of American college fraternities (20th ed.). Indianapolis, IN: Baird's Manual Foundation. (Original work published 1879)

Asel, A. M., Seifert, T. A., \& Pascarella, E. T. (2009). The effects of fraternity/sorority membership on college experiences and outcomes: A portrait of complexity. Oracle: The Research Journal of the Association of Fraternity/Sorority Advisors, 4(2), 1-15.

Bartholow, B. D., Sher, K. J., \& Krull, J. L. (2003). Changes in heavy drinking over the third decade of life as a function of collegiate fraternity and sorority involvement: A prospective, multilevel analysis. Health Psychology, 22(6), 616-626. doi:10.1037/0278-6133.22.6.616

Biddix, J. P., Matney, M., Norman, E., \& Martin, G. (2014). The influence of fraternity and sorority involvement: A critical analysis of research (1996-2013). ASHE Higher Education Report Series (Vol. 39, no. 6). San Francisco, CA: JosseyBass.

Bogdan, R. C., \& Biklen, S. K. (1998). Qualitative research for education: An introduction to theory and methods (3rd ed.). Boston, MA: Allyn and Bacon.

Brooks, S. R. (1986). Freedom's twins. Inter Fratres. Oxford, OH: [redacted].

Bryant, A. N., Gaston Gayles, J., \& Davis, H. A. (2012). The relationship between civic behavior and civic values: A conceptual model. Research in Higher Education, 53(1), 76-93. doi:10.1007/s11162-011-9218-3

Bureau, D., Schendel, K., \& Veldkamp, S. (2006, Summer) SummerValues \& action congruence. Perspectives, $16-17$.

Bureau, D. A., Ryan, H. G., Ahren, C., Shoup, R., \& Torres, V. (2011). Student learning in fraternities and sororities: Using NSSE data to describe members' participation in educationally meaningful activities in college. Oracle: The Research Journal of the Association of Fraternity/Sorority Advisors, 6(1), 1-22.

Butin, D. W. (2010). Service-learning in theory and practice: The future of community engagement in higher education. New York, NY: Palgrave McMillian.

Carnegie Foundation (2006). Higher education: Civic mission \& civic effects (Paper 128). Retrieved from http://digital commons.unomaha.edu/slcehighered/128

Colby, A., Ehrlich, T., Beaumont, E., \& Stephens, J. (2003). Educating citizens: Preparing America's undergraduates for lives of moral and civic responsibility. San Francisco, CA: Jossey-Bass.

Cruce, T. M., \& Moore, J. V., III. (2007). First-year students' plans to volunteer: An examination of the predictors of community service participation. Journal of College Student Development, 48(6), 655-673. doi:10.1353/ csd.2007.0063

Cruce, T. M., \& Moore, J. V., III. (2012). Community service during the first year of college: What is the role of past behavior? Journal of College Student Development, 53(3), 399-417. doi:10.1353/csd.2012.0038

Dey, E. L., \& Associates. (2009). Civic responsibility: What is the campus climate for learning? Washington, DC: Association of American Colleges and Universities.

Dugan, J. P. (2008). Exploring relationships between fraternity and sorority membership and socially responsible leadership. Oracle: The Research Journal of the Association of Fraternity Advisors, 3(2), 16-25.

Dugan, J. P., \& Komives, S. R. (2010). Influences on college students' capacities for socially responsible leadership. Journal of College Student Development, 51(5), 525-549. doi:10.1353/csd.2010.0009

Earley, C. (1998). Influencing ethical development in Greek letter organizations. New Directions for Student Services, 1998, 39-47. doi:10.1002/(ISSN)1536-0695

Finley, A. (2011). Civic learning and democratic engagements: A review of the literature on civic engagement in post-secondary education. (Paper prepared for the US Department of Education as part of Contract: ED-OPE-10-C-0078.). Retrieved from University of Wisconsin-Eau Clarie University Senate: https://www.uwec.edu/usenate/SenateCommittees/APC/1213/ 121030LiteratureReviewCivicEngagement.pdf

Franklin Square Group. (2003). A call for values congruence. Retrieved from http://www.afa1976.org/Portals/0/docu ments/CallForValuesCongruence.pdf

(c) NASPA 2016

http://journals.naspa.org/jcc

doi: $10.1080 / 2194587 X .2016 .1230760$ 
Harper, W. R. (1905). The trend in higher education. Chicago, IL: University of Chicago Press.

Hayek, J. C., Carini, R. M., O’Dey, P. T., \& Kuh, G. D. (2002). Triumph or tragedy: Comparing student engagement levels of members of Greek-letter organizations and other students. Journal of College Student Development, 43(5), 643-663.

Hurtado, S., \& DeAngelo, L. (2012). Linking diversity and civic-minded practices with student outcomes: New evidence from national surveys. Liberal Education, 98(2), 14-23.

Hurtado, S., Ruiz, A., \& Whang, H. (2012). Assessing students'social responsibility and civic learning. Paper presented at the 2012 Annual Forum of the Association for Institutional Research, New Orleans, LA.

Jackson, A., \& Iverson, S. V. (2009). Step up and do it: Fraternity and sorority members' beliefs about citizenship. Oracle: The Research Journal of the Association of Fraternity/Sorority Advisors, 4(1), 1-16.

Long, L. D., \& Snowden, A. (2011). The more you put into it, the more you get out of it: The educational gains of fraternity/sorority officers. Oracle: The Research Journal of the Association of Fraternity Advisors, 6(2), 1-14.

Lott, J. L. (2013). Predictors of civic values: Understanding student level and institutional-level effects. Journal of College Student Development, 54(1), 1-16. doi:10.1353/csd.2013.0002

Love, P. (2003). Document analysis. In F. K. Stage, \& K. Manning (Eds.), Research in the college context: Approaches and methods (pp. 83-97). New York, NY: Brunner-Routledge.

Marshall, C., \& Rossman, G. B. (1995). Designing qualitative research. Thousand Oaks, CA: SAGE.

Martin, G. L., Hevel, M. S., Asel, A. M., \& Pascarella, E. T. (2011). New evidence on the effects of fraternity and sorority affiliation during the first year of college. Journal of College Student Development, 52(5), 543-559. doi:10.1353/ csd.2011.0062

Matthews, H., Featherstone, L., Bluder, L., Gerling, A. J., Loge, S., \& Messenger, R. B. (2009). Living your letters: Assessing congruence between espoused and enacted values of one fraternity/sorority community. Oracle: The Research Journal of the Association of Fraternity Advisors, 4(1), $29-41$.

McCreary, G. R. (2014, February). The challenge of values congruence. AFA Essentials, 1-4.

McCreary, G. R., \& Schutts, J. W. (2015). Toward a broader understanding of fraternity: Developing and validating a measure of fraternal brotherhood. Oracle: The Research Journal of the Association of Fraternity/Sorority Advisors, 10(1), 31-50.

McMillan, S. J., \& Morrison, M. (2006). Coming of age with the Internet: A qualitative exploration of how the Internet has become an integral part of young people's lives. New Media Society, 8(1), 73-95. doi:10.1177/14614448806059871

National Association of Student Personnel Administrators (NASPA). (2016). Civic leaning and democratic engagement $(C L D E)$. Retrieved from https://www.naspa.org/focus-areas/civic-learning-and-democratic-engagement

National Task Force on Civic Learning and Democratic Engagement. (2012). A crucible moment: College learning and democracy's future. Washington, DC: Association of American Colleges and Universities. Retrieved from http://www. aacu.org/civic_learning/crucible/index.cfm

Pascarella, E. T., Whitt, E. J., Nora, A., \& Edison, M. (1996). What have we learned from the first year of the National Study of Student Learning? Journal of College Student Development, 37(2), 182-192.

Pettitt, J. (2008,) Spring Social justice: When diversity isn't enough. Perspectives, 12-13.

Roberts, D., \& Huffman, E. (2005). Learning citizenship: Campus-based initiatives for developing student change agents. About Campus, 10(4), 17-22. doi:10.1002/abc.138

Roberts, D. C., \& Johnson, M. (2006). Involving students in securing a future for fraternal organizations. Oracle: The Research Journal of the Association of Fraternity Advisors, 2(2), 74-80.

Shalka, T. R., \& Jones, S. R. (2010). Differences in self-awareness related measures among culturally based fraternity, social fraternity, and non-affiliated college men. Oracle: The Research Journal of the Association of Fraternity/ Sorority Advisors, 5(1), 1-11.

Soria, K. M., Fink, A., Lepkowski, C. C., \& Snyder, L. (2013). Undergraduate student leadership and social change. Journal of College \& Character, 14(3), 241-252. doi:10.1515/jcc-2013-0031

Weber, R. P. (1990). Basic content analysis (2nd ed.). Newbury Park, CA: SAGE Publications, Inc.

Wuthrich, C. K. (2009). Reflections on personal responsibility: Sorority members at risk for interpersonal violence. NASPA Journal, 46(2), 228-257. 